https://doi.org/10.17816/MAJ191S191-92

\title{
PRESERVED NUMBER OF OREXIN NEURONS IN POSTMORTEM HYPOTHALAMIC TISSUE OF CHRONIC ALCOHOLICS
}

\author{
A.S. Kudriavova ${ }^{1}$, V. Meskenaite ${ }^{2}$, V.I. Mikhailov ${ }^{3}$, M. Schesny ${ }^{2}$, E.A. Korneva ${ }^{1}$, \\ Y.V. Gavrilov ${ }^{1}$, P.O. Valko ${ }^{2}$ \\ ${ }^{1}$ Institute of Experimental Medicine, Saint Petersburg, Russia; \\ ${ }^{2}$ University Hospital Zurich, Zurich, Switzerland; \\ ${ }^{3}$ Alexandrovskaya City Hospital, Saint Petersburg, Russia
}

\section{КОЛИЧЕСТВО ОРЕКСИНОВЫХ НЕЙРОНОВ В АУТОПСИЙНОЙ ТКАНИ ГИПОТАЛАМУСА У ЛЮДЕЙ С ХРОНИЧЕСКИМ АЛКОГОЛИЗМОМ}

\author{
А.С. Кудрявова ${ }^{1}$, В. Мескенаите ${ }^{2}$, В.И. Михайлов ${ }^{3}$, М. Шенси ${ }^{2}$, Е.А. Корнева ${ }^{1}$, \\ Ю.В. Гаврилов ${ }^{1}$, Ф. Валко \\ ${ }^{1}$ ФГБНУ «Институт экспериментальной медицины», Санкт-Петербург; \\ ${ }^{2}$ Университетская клиника Цюриха, Цюрих, Швейцария; \\ ${ }^{3}$ СПб ГБУЗ «Александровская больница», Санкт-Петербург
}

The hypothalamic orexin system is critically involved in addiction, including chronic alcohol abuse. Microinjection of orexin into the lateral hypothalamus increases alcohol intake in rats, while reduced immunoreactivity of orexin neurons is associated with decreased alcohol drinking. Recently, the numbers of orexin neurons were found to be increased in opiate addiction in humans [4] and cocaine addiction in rats [2], but the integrity of orexin neurons has not yet been studied in human alcoholics. We examined the hypothalamus of 9 patients of chronic alcoholism and 10 subjects without a history of alcoholism or any other neurological or psychiatric disorder. We performed immunohistochemistry for orexin A, followed by stereological quantification. The hypothalamic tissue of chronic alcoholics exhibited a slightly increased number (9\%) of orexin-containing neurons compared to the control group (123'087 $\pm 18^{\prime} 536$ and 110'431 $\pm 14^{\prime} 439, p=0.11$ ). Mean Gundersen's coefficient of error was $0.06 \pm 0.01$. The number of orexin neurons was similar in chronic alcoholics and control subjects without a history of alcoholism. Further examination of alcohol-induced hypothalamic damage is needed to understand, whether a neuroplastic increase in orexin neurons counterbalances a concurrent alcohol-toxic damage to these neurons.

Keywords: alcohol; orexin; hypothalamus.

Орексинергическая система гипоталамуса критически вовлечена в формирование зависимостей, включая хроническое злоупотребление алкоголем. Микроинъекция орексина в область латерального гипоталамуса увеличивает потребление алкоголя у крыс, в то время как снижение иммунореактивности орексиновых нейронов связано со снижением потребления алкоголя. Недавно было обнаружено, что число орексиновых нейронов увеличивается при опиатной зависимости у людей [4] и при кокаиновой зависимости у крыс [2], но до сих пор состояние орексиновых нейронов у людей с алкогольной зависимостью не изучалось. Мы исследовали гипоталамус 9 пациентов с алкоголизмом и 10 пациентов без алкоголизма и любых других неврологических или психических расстройств. Мы выполнили иммуногистохимию для орексина А с последующей стереологической количественной оценкой. В гипоталамусе больных алкоголизмом было небольшое увеличение количества (9\%) нейронов, содержащих орексин, по сравнению с контрольной группой (123’087 $\pm 18^{\prime} 536$ и 110'431 $\pm 14^{\prime} 439$, $p=0,11)$. Средний коэффициент погрешности Гундерсена составил $0,06 \pm 0,01$. Количество орексиновых нейронов было одинаковым у лиц с алкоголизмом и контрольных субъектов без зависимости. Необходимо дальнейшее изучение вызванного алкоголем повреждения гипоталамуса, чтобы понять, уравновешивает ли нейропластическое увеличение количества орексиновых нейронов параллельное алкогольно-токсическое повреждение этих нейронов.

Ключевые слова: алкоголь; орексин; гипоталамус.

Introduction. It is well established that orexin system is strongly related to addiction to drugs and especially alcohol. Several studies reported that orexin neurons in lateral hypothalamus may be involved in reward and motivation [1]. Schneider et al. showed that microinjection of orexin A into the lateral hypothalamus or paraventricular nucleus of the hypothalamus increased alcohol intake in rats [3]. The numbers of orexin neurons were found to be increased in opiate addiction in humans [4] 
and cocaine addiction in rats [2], but the integrity of orexin neurons has not yet been studied in human alcoholics. Considering these data, we wondered whether long-term alcohol use would affect the number of orexin neurons in the hypothalamus in humans.

Material and methods. We studied the effect of alcohol addiction on brain orexin neurons on postmortem human hypothalamic tissue of alcoholics and non-alcoholics (control subjects). Diagnoses were based on hospital records, available for all 19 cases. All control subjects had no clinical evidence of any neurological or psychiatric disorder. Subjects having disorders or medications affecting CNS, history of drug abuse were excluded from the study. We immunostained hypothalamic sections for orexin A (hypocretin-1) as previously described [5]. The total number of positively labeled orexin A neurons was estmated using a Zeiss (Oberkochen, Germany) Axiophot microscope with a motorized stage interfaced with a Stereo Investigator system (MBF Biosciences, Willston, VT).
Results and discussion. We found no significant difference between alcoholics and control subjects. Specifically, the total number of orexin A neurons in the alcoholic patients was more $(9 \%)$ than in control subjects $(123087 \pm 18536$ and $110431 \pm 14439$, respectively, with $p=0.11$ ).

We found that the number of orexin neurons in lateral hypothalamus in alcoholic patients is no statistically different from the number in non-alcoholic subjects. Even not considering the increased $p$-value, the difference between alcoholics and non-alcoholics remains very small $(>10 \%)$, that is surprising because theoretically we could expect the number of orexin neurons be reduced due to neurotoxic effects of alcohol or increased due to their involvement in addiction and neuroplastic effects. This finding allows us to assume that the orexin system is stronger involved in opiate/cocaine addiction than alcohol addiction. However, our work continues, and with additional research, we could find out more about the integrity of the orexin neurons in alcoholism.

\section{References}

1. Harris GC, Aston-jones G. Arousal and reward: a dichotomy in orexin function. TRENDS in Neurosciences. 2006;10(29):571-577.

2. James MH, et al. Increased Number and Activity of a Lateral Subpopulation of Hypothalamic Orexin/ Hypocretin Neurons Underlies the Expression of an Addicted State in Rats. Biological Psychiatry. 2018.

3. Schneider ER, et al. Orexigenic peptides and alcohol intake: Differential effects of orexin, galanin, and ghrelin. Alcoholism: Clinical and Experimental Research. 2007;11(31):1858-1865.

4. Thannickal TC, et al. Opiates increase the number of hypocretin-producing cells in human and mouse brain and reverse cataplexy in a mouse model of narcolepsy. Science Translational Medicine. 2018;447(10):eaao4953.

5. Valko PO, et al. Increase of histaminergic tuberomammillary neurons in narcolepsy. Annals of Neurology. 2013;(6)(74):794-804. 